\title{
"Não tenhas medo": a formação de uma cultura visionária em Portugal e as suas práticas e representaçóes no Brasil (1917-1940)
}

\author{
Carlos André Silva de Moura* \\ Universidade de Pernambuco, Recife-PE, Brasil
}

\section{RESUMO}

A política cultural laicista implementada em Portugal após a proclamação da república, em 5 de outubro de 1910, contribuiu para a formação de açôes anticlericais que tinham o objetivo de encerrar as atividades da Igreja Católica no país. Como reação, os membros do clero se empenharam nos projetos de recatolizaçáo proposta pela Cúria romana, como açôes internacionais nas primeiras décadas do século XX. Neste texto, com uma abordagem voltada para a História Cultural das Religiōes, observamos como as apariçôes de Nossa Senhora de Fátima, a partir de maio de 1917, foram utilizadas para a reafirmação do discurso eclesiástico e a construção de uma cultura visionária no mundo luso-brasileiro. Ainda em nossa narrativa, analisamos a internacionalização do culto, sobretudo, as suas práticas e representaçóes em terras brasileiras.

Palavras-chave: apariçôes marianas; Portugal-Brasil; cultura visionária; recatolização; jesuítas.

\section{ABSTRACT}

The secularist cultural policy implemented in Portugal after the proclamation of the Republic on October $5^{\text {th }}, 1910$, contributed to the shaping of anticlerical actions that were intended to terminate the activities of the Catholic Church in the country. In response, members of the clergy engaged in re-catholization projects proposed by the Roman Curia, as international actions in the first decades of the twentieth century. In this paper, which has an approach focused on the Cultural History of Religions, we observe how the apparitions of Our Lady of Fátima, from May 1917 on, were used to reaffirm the ecclesiastical discourse, and to build a visionary culture in the Luso-Brazilian world. Our narrative also analyzes the internationalization of such worship, especially its practices and representations in Brazil.

Keywords: marian apparitions; Portugal-Brazil; visionary culture; re-catholization; jesuits.

DOI - http://dx.doi.org/10.1590/2237-101X017033011

Artigo recebido em 12 de dezembro de 2015 e aprovado para publicação em 21 de setembro de 2016.

* Professor adjunto do Departamento de História da Universidade de Pernambuco (UPE). Pós-doutorando no Departamento de História na Universidade Estadual de Campinas (Unicamp). A pesquisa teve o financiamento da Fundação de Amparo à Pesquisa do Estado de Sáo Paulo (Fapesp), processo n. 2015/11467-2. E-mail: casmcarlos@yahoo.com.br 
"Não TENHAS MEdo": A FORMAÇão de UMA CUlTURA VisionáRIA EM PORTUGAL E AS SUAS PRÁTICAS E REPRESENTAÇÓES NO BRASIL (I9I7-I940)

Carlos André Silva de Moura

Le culture possono inventare arbitrariamente i propri idoli, mas devono avere una fede culturale nella fede idolatria, cioè utilizzare un codice surculturale che implica un rituale di relazioni ortopratiche della comunità. ${ }^{1}$

Os eventos que marcaram as supostas apariçóes marianas em Portugal, a partir de maio de 1917, tomaram conotaçôes políticas e sociais que contribuíram para que as mensagens atribuídas à "Senhora do Rosário" ${ }^{2}$ fossem abordados como uma intrigante temática para a História das Religiôes. A partir de documentaçóes ainda pouco exploradas pela historiografia, sobretudo as correspondências de religiosos e visionários, o nosso objetivo é desenvolver uma abordagem que nos ajude a compreender a formação de uma cultura visionária no país lusitano e suas representações no Brasil durante a primeira metade do século XX.

A temática das visóes relacionadas com a religião foi bem estudada por William A. Christian Jr., com abordagens sobre o período medieval e o renascimento. Deste modo, notamos que os eventos conferidos como revelaçóes, apariçóes ou mensagens atribuídas a santos ou imagens, sobretudo a Maria, não são uma construção exclusiva do período contemporâneo. ${ }^{3}$

Entre 1707 e 1723, o frei Agostinho de Santa Maria (1642-1728) foi responsável por elaborar um inventário com as histórias das imagens milagrosas de Nossa Senhora em Portugal e nas suas colônias, situadas na Índia Ocidental, Ásia Insular, África, Filipinas e Brasil. Nos volumes 9o e 10ํㅡㅇ o franciscano apresentou uma descrição das 340 imagens e igrejas localizadas nas regiôes Norte, Nordeste, Sudeste e Sul do Brasil. ${ }^{4}$ Com o trabalho, percebemos como as devoçóes marianas podem ser analisadas a partir de abordagens com base na longa duração.

\footnotetext{
${ }^{1}$ GASBARRO, Nicola. Religione e/o Religioni? la sfida dell'antropologia e della comparazione storico-religiosa. In: MARANHÃO Fo, Eduardo Meinberg de Albuquerque. (Org.). (Re) conhecendo o Sagrado: reflexóes teórico-metodológicas dos estudos de religiōes e religiosidades. São Paulo: Fonte Editorial, 2013, p. 99.

${ }^{2}$ Lúcia de Jesus destacou que na aparição do dia 13 de outubro de 1917 a revelaçáo se autodenominou a "Senhora do Rosário". KONDOR, Pe. Luís (Comp). Memórias da irmá Lúcia I. Fátima: Secretariado dos Pastorinhos, 2011, p. 180.

${ }^{3}$ Sobre o tema Cf. CHRISTIAN JR., William A. Apariciones en Castilla y Cataluña: S. XIV-XV. Madri: Nerea, 1990.; CHRISTIAN JR., William A. Apparitions in Late Medieval and Renaissance Spain. Princeton: Princeton University Press, 1981; CHRISTIAN JR., William A. De los santos a María. Panorama de las devociones a santuarios espańoles desde el principio de la Edad Media hasta nuestros dias. TOLOSANA, Carmelo Lison (Coord.). Temas de la antropología española. Madri: Akal, 1976, p. 49-105; CHRISTIAN JR., William A. Local Religion in Sixteenth-century Spain. Princeton: Princeton University Press, 1989.

${ }^{4}$ SANTA MARIA, Frei Agostinho de. Santuário Mariano, e História das Imagës milagrofas de Nossa Senhora, e das milagrofamente apparecidas, em graça dos Prègadores, \& dos devotos da mefma Senhora. Lisboa: Of. António Pedrozo Galrão, 1707-1723. v. 1-10.
} 


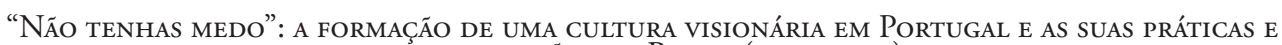
REPRESENTAÇÕES NO BRASIL (I9I7-I940)

Carlos André Silva de Moura

Durante o texto, analisamos como o culto a Nossa Senhora de Fátima contribuiu para a reação da Igreja Católica ao laicismo e ao processo de descristianização da sociedade em Portugal e no Brasil nas primeiras décadas do século passado. 5 Para isso, observamos como os intelectuais e os líderes da Cúria romana se utilizaram das narrativas em torno das apariçóes marianas, entre os dias 13 de maio e 13 de outubro de 1917, na Cova da Iria - concelho de Vila Nova de Ourém —, para os pastores Lúcia de Jesus (1907-2005), Francisco Marto (1908-1919) e Jacinta Marto (1910-1920), com 10, 9 e 7 anos, respectivamente.

Com a proposta, percebemos que o discurso recatolizador atribuído à Fátima foi resultado do trabalho dos intelectuais católicos, que tinham o objetivo de organizar açóes que reestruturassem uma Igreja Católica militante, com a proposta de novas práticas para os fiéis. ${ }^{6}$ Os eventos em torno das apariçóes na Cova da Iria aconteceram em um momento importante para os projetos da Igreja Católica em Portugal. Os últimos anos da década de 1910 foram marcados por conquistas do clero e o recuo nas perseguiçóes sofridas pelos eclesiásticos. Alguns eventos que compuseram a reação ao anticatolicismo a partir de 1917, como a acessão de Sidónio Pais (1872-1918) ao poder, o retorno das negociaçóes do Estado com o clero e a publicação do Decreto Moura Pinto, foram vistos por parte dos católicos como providências da "Senhora do Rosário".

As interpretaçóes feitas das mensagens atribuídas à Fátima estiveram relacionadas com o momento sociocultural, histórico e político, não apenas em Portugal, mas em um contexto global. Os intelectuais inseridos na hierarquia da Cúria romana trabalharam para elaborar algo novo que tomasse o lugar de uma religiáo em desgaste, com o objetivo de reorganizar o catolicismo a partir da segunda metade dos anos de $1930 .{ }^{8}$

Nicola Gasbarro nos ajudou a compreender as inserções feitas nos cultos referentes às apariçôes marianas e ao surgimento de "novos deuses". Para o autor, cada sociedade pode arbitrariamente "inventar" os seus próprios ídolos, com a utilização dos códigos que envolvem a comunidade a partir de práticas culturais inseridas na ortodoxia católica, as quais classificou

\footnotetext{
${ }^{5}$ Cf. MOURA, Carlos André Silva de. Histórias cruzadas: debates intelectuais no Brasil e em Portugal durante o movimento de Restauração Católica (1910-1942). 2015, 443 p. Tese (Doutorado em História) — Universidade Estadual de Campinas/Instituto de Filosofia e Ciências Humanas, Campinas, 2015.

${ }^{6}$ MATTOSO, José (Dir.); RAMOS, Rui (Coord.). História de Portugal: a segunda fundaçáo (1890-1926). Lisboa: Editorial Estampa, 2001. v. 6, p. 493.

${ }^{7}$ CATROGA, Fernando. Entre deuses e césares: secularização, laicidade e religião civil. Uma perspectiva histórica. Coimbra: Almedina, 2006, p. 273; NETO, Vitor. O Estado, A Igreja e a sociedade em Portugal (18321911). Lisboa: Imprensa Nacional Casa da Moeda, 1998, p. 220-221; CATROGA, Fernando. O Republicanismo em Portugal — da formação ao 5 de Outubro de 1910. Lisboa: Notícias editorial, 2000; CATROGA, 2006.; MATOS, Luís Salgado de. A Separação do Estado e da Igreja. Alfragide: D. Quixote, 2011; MOURA, Carlos André Silva de. Religião e cultura no mundo luso-brasileiro: debates sobre o projeto recatolizador (1910-1937). In: BENATTE, Antônio Paulo; CAMPIGOTO, José Adilçon (Org.). Religião e cultura: temáticas de história cultural das religiôes. Guarapuava: UNICENTRO, 2013, p. 51-74. v. I.

${ }^{8}$ MATTOSO, José (Dir.); RAMOS, Rui (Coord.). História de Portugal: a segunda fundação (1890-1926), op. cit., p. 493.
} 


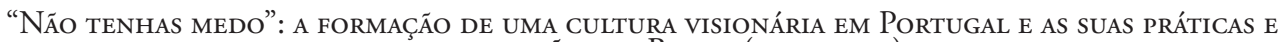
REPRESENTAÇÕES NO BRASIL (I9I7-I940)

Carlos André Silva de Moura

como ortopráticas. ${ }^{9} \mathrm{O}$ conceito abrange as regras rituais e as "açóes inclusivas e performativas da vida social”, com invençôes e reinvenções em termos de práticas religiosas. ${ }^{10}$

As notícias das aparições da "Senhora do Rosário" às três crianças na Cova da Iria, as revelaçóes dos segredos ${ }^{11}$ e a organização de um culto internacional ao Imaculado Coração de Maria foram acompanhadas por um debate político sobre o processo de laicização, da implementação da cultura laicista e da expansão do comunismo em vários países. Após o reconhecimento oficial da Igreja Católica dos eventos que marcaram as apariçóes na Cova da Iria, os líderes da Cúria romana trabalharam para silenciar não apenas as ações anticatólicas, mas também os discursos que não estavam de acordo com as orientaçôes do clero. ${ }^{12}$

É no contexto de atuação da chamada "Fátima II", ${ }^{13}$ acompanhada do processo de internacionalização das mensagens marianas, que observamos a inserção do culto no Brasil. Mesmo com o reconhecimento de todas as propostas das mensagens de Fátima, as suas atribuiçôes anticomunistas foram as mais utilizadas pelos líderes da Igreja Católica no país. O discurso contra o pensamento de esquerda colaborou com o trabalho desenvolvido por d. Sebastião Leme (1882-1942), já que este era um dos pontos de aproximação entre os poderes religioso e político nos anos 1930 .

O processo de emigração/imigração dos portugueses para o Brasil, principalmente os membros da Companhia de Jesus, cooperou para as trocas culturais relacionadas com os cultos católicos. As atividades dos jesuítas que se destinaram à cidade do Recife foram importantes para a formação do primeiro templo dedicado a Nossa Senhora de Fátima fora de Portugal.

\footnotetext{
${ }^{9}$ GASBARRO, Nicola. Religione e/o Religioni? la sfida dell'antropologia e della comparazione storico-religiosa, op. cit., p. 99.

${ }^{10}$ GASBARRO, Nicola. A modernidade ocidental e a generalização de "religião" e "civilização": o agir comunicativo das missóes. In: SILVA, Eliane Moura da; ALMEIDA, Néri de Barros (Org.). Missão e pregação: a comunicação religiosa entre a História da Igreja e a História das Religiōes. São Paulo: FAP/Unifesp, 2014, p. 190.

${ }^{11}$ Os segredos de Fátima são divididos em três partes. A primeira e a segunda mensagens foram escritas por Lúcia de Jesus em 1941 e reveladas logo em seguida, já o terceiro segredo foi escrito em 1944 em uma correspondência que deveria ser aberta apenas pelo papa. No dia 26 de junho de 2000, o Vaticano divulgou a última parte da mensagem. Os segredos consistem em: primeiro e segundo. A visão do inferno, a devoção ao Imaculado Coração de Maria, a Segunda Guerra Mundial e o prenúncio dos danos que a Rússia poderia causar à humanidade com o abandono ao cristianismo e a adesão ao comunismo. O terceiro segredo se refere ao martírio dos líderes da Igreja, sobretudo do papa, em um mundo em crise devido aos "erros da Rússia" espalhados pelo mundo.

${ }^{12}$ BARRETO, José. Religião e sociedade: dois ensaios. Lisboa: Imprensa de Ciências Sociais, 2002, p. 45.

${ }^{13}$ Estudiosos das apariçóes de Fátima atribuem dois momentos para as interpretaçóes das mensagens na primeira metade do século XX. Segundo José Barreto, o teólogo Edouard Dhanis foi um dos pioneiros no debate internacional sobre Fátima. As argumentaçôes levaram a nomenclaturas como "Fátima I", que tem sua atuação voltada para a recristianização de Portugal até meados dos anos de 1930. A segunda classificação é denominada de "Fátima II", que se baseia na sua mensagem contra o comunismo e na internacionalização do culto. BARRETO, José. A Brotéria e Fátima. In: RICO, Hermínio; FRANCO, José Eduardo (Coord.). Fé, ciência, cultura: Brotéria-100 anos. Lisboa: Gradiva, 2003, p. 412.
} 


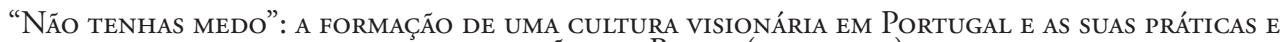
REPRESENTAÇÕES NO BRASIL (I9I7-I940)

Durante a nossa narrativa, não foi a intenção realizar um debate aprofundado sobre os três segredos atribuídos a Fátima, analisar o inquérito instaurado pela Igreja Católica sobre as suas apariçóes ou levantar questôes sobre a veracidade dos fatos ocorridos na Cova da Iria. O objetivo do texto foi perceber como o culto mariano, em Portugal e no Brasil, contribuiu para a elaboração dos discursos de recatolização, de combate ao anticlericalismo e ao comunismo nos dois países.

\section{A formação de uma cultura visionária e os seus usos no movimento de recatolização em Portugal}

Durante os eventos que marcaram a divulgação do terceiro segredo de Fátima, em maio do ano 2000, o cardeal d. Joseph Ratzinger, Prefeito da Congregação para a Doutrina da Fé, publicou o texto Comentário Teológico com questôes pertinentes às interpretaçôes das apariçôes marianas. Em seus escritos enfatizou os eventos em torno de Fátima, com algumas análises sobre os segredos que foram revelados por Lúcia de Jesus.

Referente ao terceiro segredo, o cardeal alemáo indagou se as mensagens traduzidas pelos visionários realmente refletia as palavras de Maria, “(...) Ou não serão talvez apenas projecçôes do mundo interior de crianças, crescidas num ambiente de profunda piedade, mas simultaneamente assustadas pelas tempestades que ameaçavam o seu tempo?." ${ }^{14}$

As indagações nos levaram a pensar o ambiente geográfico, político e social nos quais se deram as possíveis apariçôes marianas a partir de 13 de maio de 1917. A segunda década do século XX foi marcada por diversas crises para além das questôes religiosas, sobretudo, em algumas regióes centrais e localizadas ao norte de Portugal. Com uma tradição agrária e a maioria da população economicamente ativa voltada para o trabalho braçal, as localidades enfrentavam problemas de falta de máo de obra devido ao número de enviados à guerra, o aumento nas taxas de exílios e da imigração.

Durante o primeiro conflito mundial (1914-1918) foram mobilizados mais de 100 mil portugueses para as trincheiras, com a média de 8 mil mortos, feridos ou aprisionados. As epidemias de tifo, varíola e pneumonia atingiram as famílias mais carentes, diminuindo a expectativa de vida dos lusitanos, que se deparavam todos os anos com uma vastidão de enfermidades.

Desde 1914, os lusitanos enfrentavam a baixa oferta de trigo, matéria-prima para a base alimentar dos portugueses. Enquanto o governo republicano tentava resolver os seus problemas internos, os estabelecimentos comerciais eram saqueados por parte da população que se tornava personagem principal da chamada "revolução da fome". 15

\footnotetext{
${ }^{14}$ RATZINGER, Joseph. Comentário teológico. Disponível em: <http://www.vatican.va/roman_curia/congregations/cfaith/documents/rc_con_cfaith_doc_20000626_message-fatima_po.html> Acesso em: 2 abr. 2014. ${ }^{15}$ MATTOSO, José (Dir.); RAMOS, Rui (Coord.). História de Portugal: a segunda fundação (1890-1926), op. cit., p. $453,454$.
} 
A falta de estrutura pública também dificultava a organização dos meios que possibilitavam melhorias econômicas. Em 1917, a cidade de Lisboa ficava às escuras nas primeiras horas da noite, os eléctricos não funcionavam e os integrantes da polícia não se apresentavam para o trabalho. Sem os serviços de transporte e de segurança, a produção do Norte não tinha como escoar para as outras regióes, dificultando os esforços por melhores condições sociais.

Os problemas econômicos, a crise na saúde e o medo das ameaças da guerra despertaram a necessidade do revigoramento da fé. Para tentar resolver as problemáticas que foram expostas, alguns católicos se apegaram às manifestaçôes que eram traduzidas como a salvação para Portugal. ${ }^{16}$ No início do século XX foi criada uma cultura visionária, a partir de mensagens com conotaçóes políticas e sobre o momento histórico vivenciado.

É importante destacar que os eventos relacionados com Nossa Senhora de Fátima em 1917 não foram os únicos registrados em Portugal na primeira metade do século XX. O período foi marcado por várias outras apariçóes/visôes e se classificou como o século de ouro do culto mariano. ${ }^{17}$ As mensagens de Fátima se popularizaram devido ao trabalho dos intelectuais católicos para criar uma identidade com a nacionalidade e uma centralidade no catolicismo português..$^{18}$

Em 1915 Lúcia de Jesus teve sua primeira experiência de revelação privada. Ao completar 7 anos de idade, iniciou seu trabalho de pastoreio das ovelhas da família em localidades próximas às terras do seu pai. Em uma das ocasióes, juntamente com as crianças Teresa Matias, Maria Rosa e Maria Justino, afirmou ter presenciado o surgimento de algo "como que suspensa no ar, sobre o arvoredo, uma figura como se fosse uma estátua de neve que os raios do sol tornavam algo transparente"..$^{19}$ Em suas memórias, a irmá Lúcia destacou que durante o evento não foi travado nenhum diálogo com a imagem, apenas uma visão compartilhada entre as três crianças.

Ainda em 1916, os primos de Lúcia de Jesus, Francisco e Jacinta Marto, começaram a acompanhá-la no trabalho que era realizado diariamente. Em determinado momento, na propriedade denominada de Chousa Velha, as crianças afirmaram que após um vento forte viram sobre o olival “(...) um jovem dos seus 14 ou 15 anos, mais branco que se fora de neve, que o sol tornava transparente como se fora de cristal e duma grandeza”. ${ }^{20}$

Segundo os relatos da irmá Lúcia, esta foi a primeira aparição nítida do anjo, que deixou uma mensagem em forma de oração. No diálogo que a religiosa afirmava ter tido com o "enviado divino" foi exposto que era necessário o "perdão para os que não creem, não adoram, não esperam e não Vos amam [Deus/Jesus/Maria]”. ${ }^{21}$

${ }^{16}$ TORGAL, Luís Felipe. O sol bailou ao meio-dia: a criação de Fátima. Lisboa: Tinta-da-China, 2011, p. 22.

17 REIS, Bruno Cardoso. Fátima: a recepção nos diários católicos (1917-1930). Análise Social, Lisboa, v. XXXVI (158-159), p. 249-299 [p. 272-273], 2001.

${ }^{18}$ FONTES, Paulo Fernando de Oliveira. Elites católicas em Portugal: o papel da Acção Católica (1940-1961). Lisboa: Fundação Calouste Gulbenkian/Fundação para a Ciência e Tecnologia, 2011, p. 91.

${ }^{19}$ KONDOR, Pe. Luís (Comp.) Memórias da irmã Lúcia I, op. cit., p. 75.

${ }^{20}$ Ibidem, p. 77.

${ }^{21}$ Idem. 
"Não TENHAS MEdo": A FORMAÇão de UMA CUlTURA VisionáRIA EM PORTUGAL E AS SUAS PRÁTICAS E REPRESENTAÇÕES NO BRASIL (I9I7-I940)

Outras supostas revelaçôes foram se sucedendo com mensagens importantes para se compreender os eventos em torno das apariçóes marianas a partir de 1917. Na segunda aparição, o anjo destacou o papel que as três crianças teriam e a sua importância para o catolicismo no país. Durante o novo diálogo informou-os que:

(...) Os Corações Santíssimos de Jesus e Maria têm sobre vós desígnios de misericórdia. Oferecei constantemente, ao Altíssimo, oraçóes e sacrifícios.

- Como nos havemos de sacrificar? - perguntei [Lúcia de Jesus].

- De tudo que puderdes, oferecei a Deus sacrifício em acto de reparação pelos pecados com que Ele é ofendido e súplica pela conversão dos pecadores. Atrai assim, sobre a vossa Pátria, a paz. Eu sou o Anjo da sua guarda, o Anjo de Portugal. Sobretudo, aceitai e suportai, com submissão o sofrimento que o Senhor vos enviar. ${ }^{22}$

A irmã Lúcia e alguns membros da Igreja Católica que se debruçaram sobre os estudos das apariçôes de Fátima afirmaram que os primeiros contatos serviram como preparação para os acontecimentos que ocorreram a partir de maio de 1917. As três crianças eram tidas como as mensageiras dos caminhos para a salvação de Portugal, por isso precisariam se preparar para o que estava por vir.

A terceira e última aparição do anjo foi em um momento de oração, quando surgiu “(...) tendo em sua mão esquerda um Cálix, sobre o qual está suspensa uma Hóstia, da qual caem algumas gotas de Sangue dentro do Cálix!”. Segundo a irmã Lúcia, após a visão o anjo se ajoelhou para uma oração oferecida a "Santíssima Trindade" em reparação aos pecados cometidos na terra. Durante o diálogo, o anjo teria destacado a importância da conversão dos "pobres pecadores". ${ }^{23}$

As primeiras experiências tidas pelos pequenos pastores se diferenciaram das ocorridas na Cova da Iria pela divulgação do evento, recepção dos habitantes da regiáo, aceitação dos fiéis e os usos que os membros da Igreja Católica fizeram do caso. As notícias das visóes do anjo ficaram resumidas ao espaço familiar e a alguns moradores em torno da propriedade dos pais dos visionários.

No entanto, as primeiras revelaçôes resguardaram os princípios necessários para o reconhecimento de uma aparição privada pela Igreja Católica. A partir dos ensinamentos da instituição, os eventos em torno das visões necessitavam atender alguns aspectos doutrinários para o seu reconhecimento: $1^{\circ}$ que a mensagem não contenha nada em contraste com a fé e os bons costumes; $2^{\circ} \mathrm{o}$ evento pode se tornar público; $3^{\circ}$ os fiéis ficam autorizados a aderir às mensagens da revelaçáo como um auxílio para compreender o evangelho. ${ }^{24}$

\footnotetext{
${ }^{22}$ Ibidem, p. 78.

${ }^{23}$ Ibidem, p. 79.

${ }^{24}$ RATZINGER, Joseph. Comentário teológico, op. cit.
} 


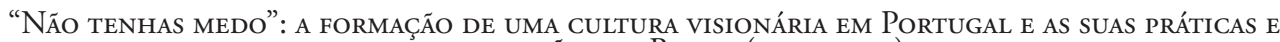
REPRESENTAÇÕES NO BRASIL (I9I7-I940)

A adoção do conceito de revelação ou aparição pela Igreja Católica é relevante, uma vez que, entre os seus requisitos, existe a necessidade de se tornar um momento público. Tal questão se diferencia do termo visão, que é entendido como um momento particular, com aspectos que se resumem a sentimentos interiores. ${ }^{25}$

Para a análise dos acontecimentos relacionados com a Fátima, utilizamos o conceito de apariçóes ou revelaçóes, que fazem parte de um conjunto conhecido como apariçóes/ revelaçóes marianas. No entanto, não descartamos que as primeiras experiências de Lúcia de Jesus podem ser consideradas visóes privadas, que também são reconhecidas pela Igreja Católica.

Percebemos que os eventos em torno das apariçôes marianas envolveram crianças, de regiốes pobres e não alfabetizadas, como as divulgadoras das mensagens que deveriam ser direcionadas ao público. Para os líderes da Cúria romana, no momento das revelaçóes, "A pessoa é levada para além da pura exterioridade, onde é tocada por dimensôes mais profundas da realidade que se lhe tornam visíveis". A partir da afirmação, a Igreja Católica explica o papel desses personagens, já que a alma de cada um estaria, ainda, "pouco alterada, e quase intacta a sua capacidade interior de percepçáo". ${ }^{26}$

Em maio de 1917, Lúcia de Jesus, Jacinta e Francisco Marto foram personagens de novos eventos. No entanto, os acontecimentos apresentaram objetivos e mensagens direcionadas ao contexto sociopolítico do momento, com a intervenção direta da Igreja Católica. Neste instante, teve início a construção da imagem de Nossa Senhora de Fátima como a responsável pela salvação sociopolítica em Portugal. As mensagens abordadas, entre maio e outubro de 1917, foram consideradas as mais proféticas das apariçôes marianas na modernidade, acompanhadas pelos eventos em torno de Nossa Senhora de Lourdes, na França, em $1858 .{ }^{27}$

Os eventos entre maio e outubro de 1917 foram importantes para a reafirmaçáo da presença da Igreja Católica no mundo rural, mas principalmente para o reestabelecimento ideológico da instituição na região. O culto a Nossa Senhora de Fátima contribuiu para a retomada das conversôes ao catolicismo, com características nacionalistas e antiliberais, com críticas ao laicismo e ao anticlericalismo republicano. ${ }^{28}$

${ }^{25}$ BARRETO, José. Religião e sociedade: dois ensaios, op. cit., p. 65.; CHRISTIAN JR., William A. Visionaries: The Spanish Republic the Reign of Christ. Los Angeles: University of California Press, 1996.

${ }^{26}$ RATZINGER, Joseph. Comentário teológico, op. cit. Os casos das apariçôes marianas em La Salette (França, 1846), Lourdes (Franças, 1858), Fátima (Portugal, 1917) e Garabandal (Espanha, 1961) tiveram as crianças como interlocutora das mensagens.

${ }^{27}$ BERTONE, Tarcisio, SDB. A mensagem de Fátima. Disponível em: <http://www.vatican.va/roman_curia/ congregations/cfaith/documents/rc_con_cfaith_doc_20000626_message-fatima_po.html>. Acesso em: 2 abr. 2014. A primeira aparição de Nossa Senhora de Lourdes teria acontecido na França em 11 de fevereiro de 1858, testemunhada por Bernadette Soubirous, de 14 anos, sua irmã Toinette Soubirous e a amiga Jeanne Abadie, ambas de 12 anos. O evento ocorreu no ano previsto por Nossa Senhora em uma apariçáo na cidade de La Salette, em 19 de setembro de 1846, para Maximin Giraud, de 11 anos, e Mélanie Calvat, de 15 anos. ${ }^{28}$ SIMPSON, Duncan. A Igreja Católica e o Estado Novo salazarista. Lisboa: Ediçóes 70, 2014, p. 35. 


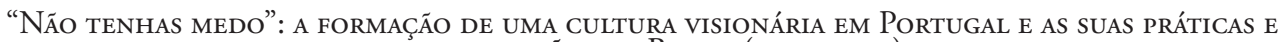
REPRESENTAÇÕES NO BRASIL (I9I7-I940)

A primeira aparição da "Senhora do Rosário" aconteceu em 13 de maio de 1917, enquanto as crianças cuidavam do rebanho de ovelhas na propriedade dos seus pais, conhecida como Cova da Iria. O lugar era considerado impróprio para a agricultura, com a resistência apenas das azinheiras ${ }^{29} \mathrm{em}$ alguns períodos do ano.

Segundo os relatos, durante o dia de trabalho os pastores presenciaram dois relâmpagos, seguidos do surgimento de uma mulher vestida de branco em cima de uma das árvores típicas da regiâo. No diálogo que se afirma ter havido entre as crianças e Nossa Senhora de Fátima, falou-se que o evento se repetiria na mesma data por mais cinco meses, que os três visionários iriam para o céu e que no momento náo se poderia informar quando a guerra acabaria. $^{30}$

A angústia sobre os desdobramentos do primeiro conflito mundial era uma das principais preocupaçóes dos portugueses durante a década de 1910. As incertezas, as crises, os rumos a serem seguidos e a esperança pelo fim do evento bélico estavam na ordem do dia dos portugueses, que se refletiam nos atos religiosos, a exemplo do primeiro diálogo entre os três pastores e Nossa Senhora de Fátima.

A distância do Concelho de Vila Nova de Ourém dos principais centros urbanos dificultou a divulgaçáo imediata do evento. As notícias ficaram restritas à regiâo central de Portugal, tornando-se popular a partir da segunda aparição em 13 de junho de 1917, mas ainda com pequenos relatos sobre o ocorrido.

O jornal $O$ Seculo foi o primeiro em âmbito nacional a noticiar os eventos das apariçóes marianas. A matéria publicada em 23 de julho de 1917 se limitou a apresentar a notícia sem uma crítica referente ao acontecido. O periódico Liberdade foi o pioneiro entre os católicos, com a publicação de uma reportagem descritiva em 17 de agosto de 1917..31

Em maio de 1931, a revista Brotéria divulgou um artigo com análises sobre as proximidades entre as apariçôes de Nossa Senhora de Fátima e os eventos ocorridos em Lourdes. Entre a discussão, o autor apresentou o depoimento de Maria dos Santos, que acompanhou os momentos das revelaçóes da "Senhora do Rosário", exceto a ocorrida no dia 13 de maio de 1917. A moradora relatou que:

Á hora aprazada appareceram as três crianças, e aqui, debaixo desta azinheira, rezaram o terço. No fim levantou-se a Lúcia, ageitou o chale e o lenço branco que lhe cobria a cabeça, compôs-se tôda como para entrar numa igreja, e virou-se para o nascente, aguardando a

\footnotetext{
${ }^{29}$ Árvore típica da região da Cova da Iria, a história das apariçóes está relacionada com a presença da azinheira na localidade. Resistente à aridez e ao solo pedregoso, a árvore foi vista como uma "benção" para os eclesiásticos que interpretaram o evento religioso. Em janeiro de 2007, a Direcção-Geral dos Recursos Florestais classificou a azinheira situada ao lado da Capelinha das Apariçôes de "interesse público", por sua relaçáo com o ocorrido a partir de maio de 1917. AZEVEDO, Carlos Moreira; CRISTINO, Luciano (Coord.). Enciclopédia de Fátima. Estoril: Princípia, 2007, p. 67-68.

${ }^{30}$ TORGAL, Luís Felipe. O sol bailou ao meio-dia: a criação de Fátima, op. cit., p. 41.

${ }^{31}$ REIS, Bruno Cardoso. Fátima: a recepção nos diários católicos (1917-1930), op. cit., p. 253.
} 


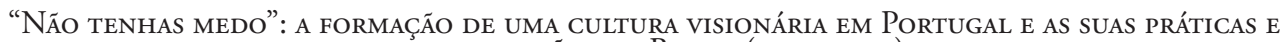
REPRESENTAÇÕES NO BRASIL (I9I7-I940)

Carlos André Silva de Moura

visão. Ás pessoas presentes que lhe perguntavam se havia demora, respondia que não. Os dois primos insistiam em que ainda havia tempo para rezarem o terço, quando Lucia manifestou o impulso de surpresa, dizendo “já se viu o relâmpago, já lá vem a Senhora” e correu para a carrasqueira, seguindo-a os primos. Ouvi o que Lúcia disse à visão, porém não vi nada, nem ouvi respostas. Reparei contudo numa coisa notável. Era em junho; a carrasqueira tinha tôda a copa coberta de rebentos novos, compridos. Quando a Lúcia, terminada a apparição, significou que a Senhora se havia ido para a banda do nascente, todos os rebentos da carrasqueira estavam acamados e voltados para o oriente, como se a orla do vestido da Senhora, ao partir, tivesse roçado sobre êlles. ${ }^{32}$

O exposto por Maria dos Santos demonstrou uma das principais distinçóes entre a visão, como algo privado, e a aparição como o momento em que existe a participação e comprovação de outros presentes. Mesmo sem enxergar Nossa Senhora de Fátima, a moradora da região destacou o movimento da carrasqueira como uma comprovação da sua presença.

As notícias sobre as apariçóes de Nossa Senhora despertaram a curiosidade dos populares e a atenção dos membros do governo, já que a lei de separação entre o Estado e a Igreja, publicada em 20 de abril de 1911, proibia tais manifestaçôes no artigo 55‥33 A cada reunião das crianças, aumentava o número de seguidores que, crentes ou incrédulos, queriam conferir a veracidade dos eventos. A desconfiança sobre as afirmaçóes de Lúcia também era recorrente entre os seus familiares, inclusive a sua mãe, que a pressionava para confessar as possíveis fantasias criadas com os primos. ${ }^{34}$

Os eventos recorrentes às apariçóes foram acontecendo nas datas estabelecidas no dia 13 de maio de 1917. No entanto, em 13 de agosto, Artur de Oliveira Santos (1884-1955), membro do Partido Republicano Português, integrante da maçonaria e administrador do Concelho de Vila Nova de Ourém, empenhado em acabar com as manifestaçóes e evitar a divulgação das apariçóes, decidiu deter Lúcia de Jesus, Francisco e Jacinta Marto.

$\mathrm{O}$ representante político levou as crianças para a sua residência por dois dias, evitando que comparecessem à Cova da Iria no dia e horário marcados. Durante este período, Artur de Oliveira Santos realizou interrogatórios e ameaças para que Lúcia de Jesus revelasse os segredos e não retomasse as suas histórias. Sem sucesso, o administrador autorizou o regresso dos visionários para as suas casas. ${ }^{35}$

\footnotetext{
32 TAVARES, J. S. Fátima e Lourdes. Brotéria, Lisboa, v. XII, fasc. V, p. 279-280 [p. 273-287], maio 1931.

${ }^{33}$ Diz o artigo 55: "Os actos de culto de qualquer religiáo fora dos lugares a isso destinados, incluindo os funerais ou honras fúnebres com cerimónias cultuais, importam a pena de desobediência, aplicável aos seus promotores e dirigentes, quando náo se tiver obtido, ou for negado, o consentimento por escrito da respectiva autoridade administrativa”. Decreto de 20 de abril de 1911. Diario do Governo 92, Lisboa, 21 abr. 1911; CLP, p. $430-446$.

${ }^{34}$ KONDOR, Pe. Luís (Comp.) Memórias da irmá Lúcia I, op. cit., p. 82-83.

${ }^{35}$ AZEVEDO, Carlos Moreira; CRISTINO, Luciano (Coord.). Enciclopédia de Fátima, op. cit., p. 510. É importante destacar que o período das apariçốes foi marcado por um intenso anticlericalismo em Portugal.
} 


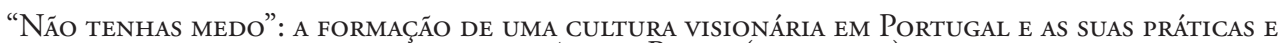
REPRESENTAÇÕES NO BRASIL (I9I7-I940)

Carlos André Silva de Moura

A esta altura era difícil evitar as aglomeraçôes na regiáo. Os principais veículos da imprensa já apresentavam textos sobre os acontecimentos na parte central de Portugal. Mesmo assim, os jornais republicanos se esforçavam para silenciar os atos dos católicos, com acusaçóes aos membros da Companhia de Jesus de usar as crianças e a população de uma região pobre, com alto número de analfabetos e fanáticos, com o objetivo de divulgar suas crenças. ${ }^{36}$

A última apariçâo de Nossa Senhora de Fátima, em 13 de outubro de 1917, foi o momento de maior destaque para o culto mariano em Portugal. Devido à divulgação na imprensa, o compartilhamento de notícias de uma possível salvadora para o país, a busca por respostas em temas relacionados com a fé - seja dos crentes ou dos incrédulos - e a necessidade de reafirmação de um catolicismo que se sentia ameaçado, os dias marcados para a "recepção" de Nossa Senhora tomaram proporçôes jamais vistas no país.

Se a quinta apariçấo foi marcada pelo silêncio e o desencanto de alguns católicos, no encontro seguinte foram "reveladas" mensagens com conotaçôes políticas e a esperança para o final da guerra. Em interrogatório e nas memórias de Lúcia de Jesus, destacou-se que o possível diálogo travado entre as crianças e a representação de Nossa Senhora se baseou em pedidos e profecias que contemplaram aspectos globais.

No dia 13 de outubro, Nossa Senhora teria comunicado, inicialmente, que todos deveriam rezar o terço e que não se deveria ofender "Deus Nosso Senhor, que já está muito ofendido". ${ }^{37}$ A "Senhora de Fátima” também solicitou que se construísse uma capela no local, ação que foi efetivada entre 28 de abril e 15 de junho de 1919. Antes de partir, teria informado que a guerra acabaria naquele dia e que os portugueses retornariam do front $\mathrm{em}$ breve. ${ }^{38}$

Mesmo que as mensagens reveladas pelos pastores na última aparição tenham sido importantes para os católicos portugueses, o fenômeno que ficou conhecido como o "bailado do sol" chamou atenção dos jornalistas, religiosos e curiosos que se encontravam na localidade. O assunto foi debatido em diversos periódicos, com diferentes conotaçôes para se explicar o ocorrido, com argumentos que se baseavam desde as obras divinas a acontecimentos naturais.

O jornalista Avelino de Almeida (1873-1932) publicou uma reportagem n'O Seculo no dia 13 de outubro de 1917, com relatos das expectativas de se observar um evento que não era novo para a Igreja Católica. Mesmo que na infância tenha tido contato com os ensinamentos católicos, o repórter fez consideraçóes céticas baseadas nas possibilidades mercadológicas que poderiam ser obtidas dos acontecimentos na Cova da Iria. ${ }^{39}$

Após a Proclamação da República, representantes do novo sistema político se empenharam em promover uma "limpeza" das manifestaçôes religiosas, com o projeto de encerrar as atividades do catolicismo no país. Sendo assim, consideramos que as propostas para a separação entre o Estado e a Igreja ultrapassaram o conceito de secularização e laicização, classificando-se como um projeto político laicista. MOURA, 2015, p. 23-43.

${ }^{36}$ TORGAL, Luís Felipe. O sol bailou ao meio-dia: a criação de Fátima, op. cit., p. 46-47.

${ }^{37}$ KONDOR, Pe. Luís (Comp.) Memórias da irmã Lúcia I, op. cit., p. 97.

${ }^{38}$ TORGAL, Luís Felipe. O sol bailou ao meio-dia: a criação de Fátima, op. cit., p. 49. A Primeira Guerra Mundial durou até 11 de novembro de 1918.

${ }^{39}$ AZEVEDO, Carlos Moreira; CRISTINO, Luciano (Coord.). Enciclopédia de Fátima, op. cit., p. 22-24. 
No artigo em questão, Avelino de Almeida destacou a constante ocorrência de testemunhos religiosos em momentos de provaçôes, como os vivenciados em Portugal desde o início do século XX. Segundo o jornalista, a populaçáo não precisava ficar assustada no caso de “(...) se descobrir que as faladas apariçôes de Fátima redundaram, sobretudo, em vantagens temporaes para muita gente...”. ${ }^{40}$

No entanto, após o dia 13 de outubro, as reportagens divulgadas por vários jornalistas, inclusive Avelino de Almeida, apresentaram uma abordagem amena em relação aos fatos ocorridos na Cova da Iria. Os textos publicados pelo republicano fizeram uma análise social, antropológica e cultural do evento, despertando sentimentos divergentes entre integrantes do governo e os católicos que trabalhavam para a construção da imagem de Fátima como recristianizadora de Portugal. ${ }^{41}$

Em artigo também publicado n'O Seculo, Avelino de Almeida descreveu como a regiáo de Vila Nova de Ourém estava no dia marcado para a última aparição. Em sua exposição, destacou que os fiéis caminhavam descalços, rezando o terço em direção à Cova da Iria, com a intenção de dormir o mais próximo possível da azinheira que já era considerada sagrada. Mesmo com uma forte devoção, os peregrinos eram vítimas de chacotas proferidas por alguns céticos que os esperavam no caminho que percorriam. ${ }^{42}$

Segundo o jornalista, a localidade foi tomada por mais de 40 mil peregrinos e curiosos que queriam conferir a veracidade sobre a aparição de Maria. Nota-se que durante as últimas revelaçôes a região da Cova da Iria já tinha se tornado um espaço de devoção e peregrinação, mesmo sem a Igreja Católica apresentar o reconhecimento oficial do evento.

O texto foi concluído com o relato do caso do "bailado do sol", que ficou marcado para os católicos como a principal demonstração da veracidade das revelaçôes às três crianças. Segundo o jornalista, que já tinha questionado a exploraçáo em torno dos eventos na Cova da Iria, no horário estabelecido para a aparição de Nossa Senhora:

(...) assiste-se entấo a um espetáculo único e inacreditável para quem não foi testemunha d'ele. Do cimo da estrada, onde se aglomeram os carros e se conservam muitas centenas de pessoas (...), vê-se toda a imensa multidão voltar-se para o sol, que se mostra liberto de nuvens, no zenit. O astro lembra uma placa de prata fosca e é possivel atar-lhe o disco sem o mínimo esforço. Não queima, não cega. Dir-se-hia estar-se realisando um eclipse. Mas eis que um alarido colossal se levanta, e aos espectadores que se encontram mais perto se ouve gritar. — Milagre, milagre! Maravilha, uma maravilha! Aos olhos deslumbrados d'aquele povo, cuja atitude nos

\footnotetext{
${ }^{40}$ ALMEIDA, Avelino de. Em pleno sobrenatural: As aparições de Fátima. Milhares de pessoas concorrem a uma charneca nos arredores de Ourem, para verem e ouvirem a Virgem Maria. O Seculo, Lisboa, p. 1, 13 out. 1917c.

${ }^{41}$ TORGAL, Luís Felipe. O sol bailou ao meio-dia: a criação de Fátima, op. cit., p. 52.

${ }^{42}$ ALMEIDA, Avelino de. Coisa Espantosa. Como o sol Bailou ao Meio dia em Fátima. O Seculo, Lisboa, p. 1, 15 out. 1917a.
} 
"Não TENHAS MEdo": A FORMAÇão de UMA CUlTURA VisionáRIA EM PORTUGAL E AS SUAS PRÁTICAS E REPRESENTAÇÕES NO BRASIL (I9I7-I940)

Carlos André Silva de Moura

transporta aos tempos bíblicos e que, pálido de assombro, com a cabeça descoberta, encara o azulão sol tremeu, o sol teve nunca vistos movimentos bruscos fóra de todas as leis cósmicas o sol «bailou» segundo a típica expressão dos camponezes... ${ }^{43}$

A reportagem agradou setores da Igreja Católica, que ainda se mantinham cautelosos em relação ao ocorrido, pois necessitavam de uma análise aprofundada e de "comprovaçóes" sobre as revelações feitas às três crianças. A manifestação pública de Fátima era um pré-requisito para a Cúria reconhecer o evento. Sendo assim, os relatos sobre o "bailado do sol" contribuíram com a construção da imagem de Fátima como salvadora e principal responsável pela recatolização em Portugal.

O acontecido na Cova da Iria em 13 de outubro de 1917 colaborou com a formação do caráter milagroso de Fátima, tendo como base os testemunhos sobre o "milagre do sol". $\mathrm{O}$ evento foi o momento em que a massa de fiéis pôde "participar" das apariçóes, que a partir daquela data tornaram-se públicas. ${ }^{44}$

Do mesmo modo que parte do clero se agradou dos relatos do jornalista d'O Seculo, setores republicanos se mostravam insatisfeitos com as matérias apresentadas por Avelino de Almeida. Acusava-se o periódico e o jornalista de agir com objetivos mercantis e para agradar os fiéis que se interessavam pelo assunto. ${ }^{45}$

As tentativas de desconstrução dos relatos referentes ao "bailado do sol" partiram de diversas frentes, desde alguns membros da Igreja Católica até pensadores republicanos que combatiam o discurso milagroso de Fátima. As explicaçóes eram as mais diversas, principalmente os argumentos que tentavam elucidar o evento como um fenômeno meteorológico de encontro de duas massas de ar. ${ }^{46}$

Em 29 de outubro de 1917, o assunto sobre o "bailado do sol" retornou às páginas da revista Ilustração Portugueza. Na ocasião, Avelino de Almeida abordou algumas questóes que foram trabalhadas a partir do seu texto publicando n'O Seculo. O jornalista reafirmou suas impressóes anteriores, com análises que destacavam que se era "Milagre, como gritava o povo; fenômeno natural, como dizem sábios? Não curo agora de sabel-o, mas apenas de te afirmar o que vi... O resto é com a Ciencia e com a Egreja..." ${ }^{47}$

Mesmo com os acontecimentos relatados, alguns líderes da Igreja Católica ainda se demonstravam prudentes, principalmente na questão sobre o reconhecimento das revelaçóes

\footnotetext{
${ }^{43}$ Ibidem, p. 1-2.

${ }^{44}$ REIS, Bruno Cardoso. Fátima: a recepção nos diários católicos (1917-1930), op. cit., p. 256. Algumas obras publicadas após 1917 relatam novas ocorrências do fenômeno conhecido como o "bailado do sol". A obra As grandes maravilhas de Fátima, publicada em 1927, apresentou imagens que afirmam ser um novo acontecimento no dia 13 de maio de 1921. Cf. MONTELO, Visconde. As grandes maravilhas de Fátima: subsídios para a história das apariçôes e dos milagres de Nossa Senhora de Fátima. Lisboa: União Gráfica, 1927.

${ }_{45}$ TORGAL, Luís Felipe. O sol bailou ao meio-dia: a criação de Fátima, op. cit., p. 52.

${ }^{46}$ AZEVEDO, Carlos Moreira; CRISTINO, Luciano (Coord.). Enciclopédia de Fátima, op. cit., p. 355-358.

${ }^{47}$ ALMEIDA, Avelino de. O milagre de Fátima. Ilustração Portugueza, Lisboa, p. 356, 29 out. 1917b.
} 
às três crianças na Cova da Iria. $\mathrm{O}$ clero se manteve cauteloso devido à cultura anticlerical imposta desde 1910, à fiscalização de setores republicanos e ao trabalho dos livres-pensadores para denunciar as manobras para a restauração dos cultos católicos em desacordo com a lei de separação entre o Estado e a Igreja. ${ }^{48}$

Seja por acompanhar as propostas da reorganização da Igreja em Portugal promovida por Bento XV ou influenciado pelos acontecimentos a partir de maio de 1917, em 17 de janeiro de 1918, a Diocese de Leiria foi restaurada após meio século de supressão. Em 1920, a circunscrição religiosa foi promovida a titular, uma vez que ficou subordinada ao Patriarcado de Lisboa até a nomeação do bispo Dom José Alves Correia da Silva (1872-1957). ${ }^{49}$

$\mathrm{Na}$ bula pontifícia Quo Vehementius, o papa Bento XV não fez referências aos eventos de Fátima como incentivo determinante para a sua decisão de restaurar a diocese de Leiria. No entanto, não devemos desconsiderar a importância das aparições marianas para a decisão de reativar a circunscriçáo religiosa, principalmente durante o processo de reconhecimento das revelaçóes e para que o clero local tivesse maior liberdade na organização dos projetos relacionados com o movimento de recristianização. ${ }^{50}$

A partir de agosto de 1920, com a acessão de d. José Alves Correia da Silva como bispo de Leiria (1920-1957), a Igreja Católica desenvolveu açóes que contribuíram para o reconhecimento das revelaçôes que legitimavam o culto a Nossa Senhora de Fátima em Portugal.

Entre os projetos desenvolvidos por d. José Alves Correia, destacaram-se a compra dos terrenos em torno da Cova da Iria, o acompanhamento da vida espiritual de Lúcia de Jesus, a concessão de indulgências e de privilégios litúrgicos ao local das apariçôes, a autorização de celebração de missas, o estabelecimento de um capelão para a região e a construção da basílica iniciada em 13 de maio de 1928. O bispo também apoiou as publicações sobre a temática, com aprovaçẫo das peregrinaçôes e dos atos dos fiéis que reconheciam a autenticidade das apariçôes. ${ }^{51}$

O reconhecimento oficial da Igreja Católica foi divulgado com a Carta Pastoral sobre o culto de Nossa Senhora de Fátima, publicada em 13 de outubro de 1930. No documento, o bispo de Leiria fez uma análise do processo canônico em torno das apariçôes, com ênfase nos acontecimentos históricos, nos motivos da cautela inicial da Igreja Católica e no trabalho do clero para se chegar a uma posiçáo oficial. ${ }^{52}$

D. José Alves Correia enfatizou os pontos necessários para que a Cúria romana reconhecesse o caráter milagroso das apariçōes. $\mathrm{O}$ bispo destacou que o momento de provaçôes vivenciado em Portugal, as condiçôes sociais da regiáo e dos três pastores, as perseguições sofridas

\footnotetext{
${ }^{48}$ BARRETO, José. Religião e sociedade: dois ensaios, op. cit., p. 34, 35.

${ }^{49}$ Ibidem, p. 21.

${ }^{50}$ TORGAL, Luís Felipe. O sol bailou ao meio-dia: a criação de Fátima, op. cit., p. 142-148.

${ }^{51}$ Documentação crítica de Fátima II — Processo Canónico Diocesano (1922-1930). Fátima: Santuário de Fátima, 1999, p. 25.

${ }^{52}$ Ibidem, p. 25-26.
} 


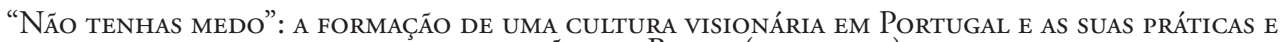
REPRESENTAÇÕES NO BRASIL (I9I7-I940)

pelas crianças e o fenômeno do "bailado do sol" foram fundamentais para que a Igreja Católica formasse o processo que tratou as apariçôes da "Senhora do Rosário" como obra divina. ${ }^{53}$

O religioso concluiu o documento declarando como "dignas de crédito as visóes das crianças na Cova da Iria (...)", compreendendo por bem "permitir oficialmente o culto de Nossa Senhora de Fátima" ${ }^{54}$ A declaraçáo publicada pelo bispo de Leiria comprovou o novo momento da Igreja Católica em Portugal, com a estruturação de projetos para a recatolização do país e uma afinidade diferente com os membros do Estado.

Foi a partir desse instante que o culto à Fátima passou a assumir um discurso essencialmente político, com a colaboração de intelectuais, como o patriarca de Lisboa d. Manuel Gonçalves Cerejeira (1888-1977), ou instituições, como a Ação Católica e o Centro Académico de Democracia Cristã (CADC). No ato de consagração da sua diocese ao imaculado Coração de Maria em 13 de maio de 1931, o patriarca apresentou o que o clero esperava de Nossa Senhora de Fátima no combate às doutrinas contrárias aos ensinamentos católicos. Os religiosos solicitaram que intercedesse na “(...) hora gravíssima em que sopram do Oriente ventos furiosos que trazem gritos de morte contra Vosso Filho (...), desvairando as inteligências, pervertendo os coraçóes, e inflamando o mundo em chamas de ódio e revolta (...)".55

Ainda durante o evento, d. Manuel Gonçalves Cerejeira agradeceu por Fátima conduzir a nação à luz e à esperança após uma longa noite vivenciada pelos portugueses. As palavras do cardeal fazem referências ao início do período republicano e às mudanças nas interpretaçôes das mensagens religiosas iniciadas em maio de 1917. Duncan Simpson destacou que um dos aspectos mais interessantes para as análises das mensagens atribuídas à "Senhora do Rosário" é a capacidade dos seus promotores ajustarem continuamente o seu conteúdo às mudanças no cenário político. ${ }^{56}$

A legitimação do culto à Fátima não contribuiu apenas para o fortalecimento da "renascença católica”. O ato também colaborou para a superação da Primeira República Portuguesa (1910-1926), marcada pelo atrito entre os membros dos poderes político e religioso, além do fortalecimento do Estado Novo salazarista. ${ }^{57}$

O culto mariano foi fundamental para a reafirmação da identidade católica em Portugal. A questão foi visível em diversos aspectos, principalmente nas formas de devoção dedicadas a Nossa Senhora de Fátima na primeira metade do século XX e a sua importância para a resolução das problemáticas entre o Estado e a Igreja no país. ${ }^{58}$

\footnotetext{
53 SILVA, D. José Alves Correia da. Carta pastoral sobre o culto de Nossa Senhora de Fátima. Lisboa: União Gráfica, 1930, p. 3, 9-12.

${ }^{54}$ Ibidem, p. 15.

${ }_{55}$ CEREJEIRA, D. Manuel Gonçalves. Obras pastorais. Primeiro Volume (1928-1935). Lisboa: União Gráfica, 1936, p. 291.

${ }^{56}$ SIMPSON, Duncan. A Igreja Católica e o Estado Novo salazarista, op. cit., p. 113.

${ }^{57}$ TORGAL, Luís Felipe. O sol bailou ao meio-dia: a criação de Fátima, op. cit., p. 136.; Cf. PINTO, António Costa; FERNANDES, Paulo Jorge. A 1ª República Portuguesa. Lisboa: CTT, 2010.

${ }^{58}$ FONTES, Paulo Fernando de Oliveira. Elites católicas em Portugal: o papel da Acção Católica (1940-1961), op. cit., p. 130.
} 


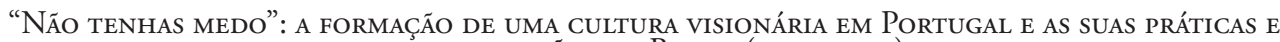
REPRESENTAÇÕES NO BRASIL (I9I7-I940)

A construção discursiva em torno de um salvador para Portugal estava relacionada diretamente com as propostas da "Fátima II". Após a década de 1930, principalmente a partir da revelação do segundo segredo, as mensagens marianas apresentaram uma conotação política que polarizavam o nacionalismo, o catolicismo e a moral, contra as doutrinas da esquerda.

Foi neste contexto político que o culto a Nossa Senhora de Fátima ganhou força no Brasil. Resultado do trabalho de imigrantes e integrantes das diversas ordens religiosas que saíram de Portugal, as mensagens de Fátima no país além-mar abordaram temas importantes para a sua recatolização e para as trocas culturais entre os intelectuais católicos.

\section{Jesuítas portugueses e as mensagens marianas em terras brasileiras}

Entre os imigrantes que desembarcaram no Brasil, os de nacionalidade portuguesa foram os que mais se destacaram. Nos últimos anos do século XIX e nas primeiras décadas do século XX, o número de lusitanos que se destinaram às diversas cidades superou os índices de todos os outros expatriados. Entre os anos de 1901 e 1930, foram contabilizadas 754.147 chegadas, já entre 1931 e 1950 são calculados 148.699 desembarques legais no país. ${ }^{59}$

Em meio ao conjunto de imigrantes que chegaram ao Brasil, estavam os membros da Igreja Católica que foram exilados de Portugal devido à cultura laicista implementada após a proclamação da República. As representaçôes formadas do clero, o trabalho em torno do movimento de Restauraçáo Católica e as aparentes afinidades entre o poder político e o religioso foram determinantes para que alguns membros da hierarquia católica portuguesa se destinassem às mais diversas regiôes. Ao se fixarem nas cidades, deram continuidade às atividades que já desenvolviam em suas dioceses, colaborando com a formação de novas práticas religiosas.

Posterior a um intenso trabalho pastoral em terras lusitanas, os jesuítas conseguiram desenvolver instituiçóes com um histórico respeitável. Durante o período de atuação, destacaram-se nas atividades em torno dos Colégios de Campolide e São Fiel, além das missóes em Macau, no Timor e na Zambésia. Ao se destinarem ao Brasil, precisaram abandonar uma estrutura construída em mais de 50 anos de trabalho.

Em 1910, a Província Portuguesa dos Jesuítas contava com 359 membros, entre eles 147 padres, 100 escolásticos e 112 irmãos, destes 69 estavam em missão. Com uma cultura missionária voltada para as regióes de influências portuguesas, o exílio dos membros da Companhia de Jesus também foi considerado um momento de atividade apostólica. ${ }^{60}$

\footnotetext{
${ }^{59}$ PAIVA, Odair da Cruz. História da (I)migração: imigrantes e migrantes em São Paulo entre o final do século XIX e o início do século XXI. Sáo Paulo: Arquivo Público do Estado, 2013.

${ }^{60}$ AZEVEDO, Ferdinand. A missão portuguesa da Companhia de Jesus no Nordeste 1911-1936. Recife: FASA, 1986, p. 7.
} 


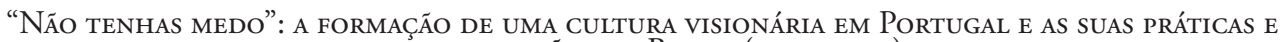
REPRESENTAÇÕES NO BRASIL (I9I7-I940)

Ao embarcarem com destino ao Brasil, os religiosos compartilhavam de um sentimento de dúvida e receio em relação à recepção dos eclesiásticos e principalmente dos governantes. Mesmo com o processo de liberdade religiosa, o país ainda estava no imaginário dos jesuítas como um lugar de onde tinham sido expulsos, principalmente com os fatos recorrentes em Portugal.

As primeiras instalações que receberam os jesuítas foram os Colégios de Nova Friburgo (Rio de Janeiro) e Itu (São Paulo), coordenados pela província romana da Companhia de Jesus. ${ }^{61}$ No lugar, os portugueses iniciaram suas atividades pastorais e os contatos para se fixarem nas diversas dioceses do país.

Com a chegada dos lusitanos, alguns bispos aproveitaram a ocasião para formar o seu clero, já que faltavam padres com especialização em estudos filosóficos e teológicos. Nos primeiros anos da década de 1910, o padre geral da Companhia de Jesus, Franz Xavier Wernz (18421914), recebeu vários pedidos para que enviasse religiosos para trabalhar nas dioceses do Brasil.

No entanto, alguns eclesiásticos não aceitaram os lusitanos de imediato. D. Joaquim Arcoverde (1850-1930) foi um dos bispos que demonstrou reservas à "interferência" dos estrangeiros nas questóes eclesiásticas do país. ${ }^{62} \mathrm{O}$ problema precisou da interferência da Cúria romana; em carta do cardeal De Lai aos líderes da hierarquia católica no Brasil, foram apresentados os problemas políticos em Portugal e a importância de receberem os "irmãos" para que pudessem superar o momento vivenciado. ${ }^{63}$

Parte da reação eclesiástica à imigração portuguesa destinada ao Brasil foi incentivada pela carta pastoral de d. Sebastiáo Leme em 1916. O texto do bispo contribuiu com a organização de um movimento conservador que valorizava o sentimento patriótico, com a gestação de uma lusofobia de caráter político, social e cultural. ${ }^{64}$

A primeira ação desempenhada pelos exilados da Companhia de Jesus foi a fundação do Colégio Antônio Vieira, em março de 1911. A instituição fazia parte dos projetos educacionais do bispo d. Jerônimo Tomé da Costa (1849-1924), que ofereceu residência aos religiosos em Santo Antônio da Barra. O estabelecimento de ensino foi o ponto de partida para outros empreendimentos dos jesuítas no Nordeste. Ainda na Bahia, as atividades dos religiosos se estenderam para Caetité, tornando-se uma das principais ligaçôes para as missóes que se destinavam ao Sertão. ${ }^{65}$

\footnotetext{
${ }^{61}$ AZEVEDO, L. Gonzaga de. Proscritos: notícias circunstanciadas do que passaram os religiosos da Companhia de Jesus na revolução de Portugal de 1910. Bruxelas: Tipografia E. DAEM, 1914. Segunda parte. p. 249. ${ }^{62}$ AZEVEDO, Ferdinand. A missão portuguesa da Companhia de Jesus no Nordeste 1911-1936, p. cit., p. 8.

${ }^{63}$ Archivio Segreto Vaticano. Nunziatura Apostolica del Brasile (1921-1925). Sacra Congregazione Concistoriale. Roma, 6 out. 1921. Busta 171, fascicolo 932. Doc. 86.

${ }^{64}$ MENDES, José Sacchetta Ramos. O apogeu da imigração portuguesa para a América do Sul (1904-1914): diversidade socioeconômica e dilemas comparativos com Itália e Espanha. In. SARMENTO, Cristina Montalvão; GUIMARÃES, Lúcia Maria Paschoal (Coord.). Culturas cruzadas em português: redes de poder e relaçôes culturais (Portugal-Brasil, séc. XIX-XX). Influências, ideários, periodismo e ocorrências. Coimbra: Almedina, 2010. v. I, p. 162-163.

${ }^{65}$ ASSUNÇÃO, Paulo. O Brasil nas páginas da Brotéria. In: RICO, Hermínio; FRANCO, José Eduardo. (Coord.). Fé, ciência, cultura: Brotéria - 100 anos. Lisboa: Gradiva, 2003, p. 458.; Cf. FOULQUIER,
} 
"Não TENHAS MEdo": A FORMAÇão de UMA CUlTURA VisionáRIA EM PORTUGAL E AS SUAS PRÁTICAS E REPRESENTAÇÕES NO BRASIL (I9I7-I940)

Os membros da Companhia de Jesus fundaram instituiçôes em São Leopoldo, São Paulo, São Luis, Belém, Fortaleza, Aracati, Salvador, Caetité, Recife, Baturité, entre outras cidades. No entanto, destacamos os projetos executados na cidade do Recife devido ao trabalho desenvolvido para o fortalecimento do culto a Nossa Senhora de Fátima no país.

D. Sebastiáo Leme, bispo de Olinda e Recife, foi o principal articulador dos projetos dos jesuítas na regiấo. Nas questôes educacionais, o religioso não se limitou à implantação apenas de uma instituição de ensino básico, intencionava organizar açôes para os diversos níveis de formação. O intuito do bispo já tinha sido apresentado em sua carta pastoral publicada em 1916.66

Para desempenhar as açôes pensadas para o Recife, em 1917 chegaram à cidade 13 jesuítas (seis padres, seis irmãos e um escolástico). Com o apoio do bispo, que facilitou a aquisição do espaço para o início das obras, em 19 de março de 1917, os membros da Companhia de Jesus inauguraram o Colégio Manuel da Nóbrega, localizado no Palácio da Soledade, residência oficial do bispado. ${ }^{67}$

A instituiçáo seguiu o modelo já aplicado pelos religiosos em outras cidades, com uma educação católica, de formação moral de jovens e a colaboração com os projetos de recatolização da sociedade. No entanto, as contribuiçóes oferecidas para o fortalecimento do culto a Nossa Senhora de Fátima e as abordagens políticas inseridas nas práticas católicas foram o que consideramos de maior relevância no trabalho dos jesuítas na cidade do Recife.

Ainda que as ideias de construção de um templo dedicado à Fátima tenham sido pensadas durante o bispado de d. Sebastiấo Leme, foi na gestáo de d. Miguel de Lima Valverde (1922-1951) que as atividades foram efetivamente executadas. O padre Joseph Foulquier ficou à frente do projeto inicial, mas devido a problemas de saúde, cedeu lugar ao padre Domingos Gomes. ${ }^{68}$

A construção do templo foi significativa para os jesuítas exilados no Brasil. Desde 1917, Fátima era referência no combate ao anticlericalismo e à cultura laicista, tinha se constituído como o principal símbolo do processo de recatolizaçáo da sociedade em Portugal. Após o reconhecimento do culto pelo bispo de Leiria e o posicionamento político das mensagens que lhe foram atribuídas, várias outras localidades passaram a organizar homenagens que contribuíram para a internacionalização do culto mariano. ${ }^{69}$

Os projetos para a construção de um templo dedicado à Fátima na cidade do Recife tiveram início antes do reconhecimento oficial do culto pela Igreja Católica. Desde 1928, o je-

Joseph H. Jesuitas no Norte: segunda entrada da Companhia de Jesus (1911-1940). Salvador: Vice-Província da Companhia de Jesus no Brasil Setentrional, 1940.

${ }^{66}$ LEME, Dom Sebastiāo. Carta pastoral saudando a sua archidiocese. Petrópolis: Typ. Vozes de Petrópolis, 1916, p. 102.

${ }^{67}$ AZEVEDO, Ferdinand. A missão portuguesa da Companhia de Jesus no Nordeste 1911-1936, p. cit., p. 115-117.

${ }^{68}$ Ibidem, p. 122.

${ }^{69}$ AZEVEDO, Carlos Moreira; CRISTINO, Luciano (Coord.). Enciclopédia de Fátima, op. cit., p. 158-164. 


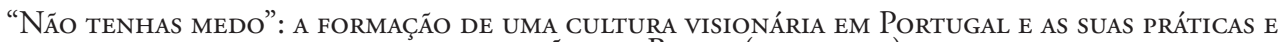
REPRESENTAÇÕES NO BRASIL (I9I7-I940)

suíta padre Manuel Rufino Negreiros foi o principal incentivador da execução de uma obra em homenagem às apariçóes marianas na capital pernambucana. Com a ajuda financeira da comunidade portuguesa, os trabalhos tiveram início em 15 de outubro de 1933, com a inauguração em 8 de setembro de 1935. A igreja foi erguida no terreno onde também se localizava o Colégio Manuel da Nóbrega, tornando-se um dos principais locais de circulação dos intelectuais católicos da cidade. ${ }^{70}$

Para popularizar o culto à Fátima entre os católicos no Recife, os jesuítas responsáveis pela direçáo do templo promoviam procissôes de vela nas ruas da cidade a cada dia 13 do mês. Além dessas manifestações, a instituição também organizou cruzadas católicas e sediou a Congregaçáo Mariana, compondo os projetos de difusão dos ensinamentos religiosos. ${ }^{71}$

A Igreja dedicada a Nossa Senhora de Fátima e o trabalho dos membros da Companhia de Jesus no Recife foram responsáveis pela expansão do culto para outras regióes do Brasil. O padre José Aparício da Silva, S. J. (1879-1966), um dos confessores de Lúcia de Jesus, foi o primeiro promulgador das mensagens da "Senhora do Rosário" fora de Portugal, e encontrou na capital pernambucana o principal ponto de divulgação para outras localidades. ${ }^{72}$

Outros templos foram erguidos nos principais centros populacionais do país. Com incentivo direto de d. Sebastião Leme, foram construídas igrejas nas cidades de Santos, Salvador, Sumaré e Rio de Janeiro. Os membros da Ordem Dominicana se dedicaram à inserçáo do culto à Fátima na região central do Brasil, como em Conceição do Araguaia entre os índios Tapirapé. Nas localidades que não foram inauguradas novas instituiçôes, edificaram-se altares em antigos e novos templos. ${ }^{73}$

Os intelectuais católicos que colaboravam com a imprensa registraram a expansão do culto a Fátima em diversas cidades do Brasil. O jornal Diario da Manhã apresentou as principais obras desenvolvidas pelos jesuítas no país. Para Laurindo Silva:

Depois da "Terra de Santa Maria”, em nenhum país o novo culto da Senhora do Rosário da Fátima vai lançando raízes mais profundas do que na grande República do Brasil. Nas suas capitais, nas cidades da beira-mar e do interior já a nova devoção progride rapidamente, vendose em construção igrejas sumptuosas, assim como altares e capelas consagradas à Senhora da Fátima a atestarem magnificamente que Maria, ao aparecer no torrão lusitano, irmão mais velho desta grande pátria, estreitou e compreendeu no seu amplexo e olhar portugueses e brasileiros irmanados pelo sangue, pela fé e agora pelo amor e devoção à Senhora do Rosário

${ }^{70}$ Boletim Mensal da Archidiocese de Olinda e Recife. Recife, ano XI, n. 10 e 11, p. 201, out./nov. 1935.; AZEVEDO, Ferdinand. A missáo portuguesa da Companhia de Jesus no Nordeste 1911-1936, p. cit., p. 125.

${ }^{71}$ FERNANDES, Antônio Paulo Ciríaco. Fátima - Santuário Mundial. Mensagem divina — Rainha da paz, chuva de graças. Recife: Ciclo Cultural Luso-brasileiro, 1944, p. 110.

${ }^{72}$ CUNHA, Maria Teresa Pereira da. Nossa Senhora de Fátima Peregrina do Mundo Através dos Continentes, a Caminho de Roma, dos Mares e dos Ares. Rio de Janeiro: Editora Santa Maria, 1953.

${ }^{73}$ FERNANDES, Antônio Paulo Ciríaco. Fátima - Santuário Mundial. Mensagem divina — Rainha da paz, chuva de graças, op. cit., p. 103, 112. 
"Não TENHAS MEdo": A FORMAÇão de UMA CUlTURA VisionáRIA EM PORTUGAL E AS SUAS PRÁTICAS E REPRESENTAÇÕES NO BRASIL (I9I7-I940)

da Fátima. (...) Em Santos, um belíssimo Santuário, ainda em construção, cuja primeira pedra foi benzida pelo Eminentíssimo Cardial Patriarca de Lisboa, D. Manoel Gonçalves Cerejeira, quando do seu regresso do Congresso Eucarístico de Buenos Aires; na Bahia, um vasto templo em construção, que se deve ao zelo e esforço dos Revdos. Padres da Companhia de Jesus; no Recife, um magnífico templo, em estilo original, o primeiro em grandes proporçóes a ser concluído no mundo inteiro em honra de N. S. do Rosário da Fátima. ${ }^{74}$

O trabalho dos membros da Companhia de Jesus foi significativo para a ampliação das trocas culturais entre brasileiros e portugueses. $\mathrm{O}$ fortalecimento do culto mariano no mundo luso-brasileiro se configurava em uma importante colaboração para a expansão do movimento internacional de Restauração Católica.

No Brasil, o culto mariano teve como foco os pontos abordados na chamada "Fátima II”, com mensagens relacionadas com o processo de conversão da Rússia e de combate ao comunismo. As inserçóes de práticas culturais elaboradas por membros da Companhia de Jesus na ortodoxia do culto contribuíram para que a imagem de Nossa Senhora de Fátima se tornasse a principal representação do combate ao pensamento de esquerda e à maçonaria.

A proposta colaborou com os projetos de implementação da moral, já que o comunismo tinha se tornado o inimigo dos poderes político e religioso. As mensagens atribuídas à Fátima respeitaram as especificidades do movimento de recatolização e as características culturais e políticas do Brasil, com abordagens relacionadas com as questóes sociais vivenciadas desde 1935.

A seguir, observamos como a imagem de Nossa Senhora de Fátima foi utilizada no combate às doutrinas de esquerda. $\mathrm{O}$ quadro foi trazido de Portugal e exposto na capela do Engenho Aruaé, na cidade de Goiana, Zona da Mata Norte de Pernambuco.

A localidade em que a imagem foi exposta, assim como os seus donos, tradicional família produtora de cana-de-açúcar no interior pernambucano, demonstrou a expansão do trabalho dos jesuítas, e dos católicos de modo geral, para popularizar as mensagens marianas. $\mathrm{O}$ apoio, tanto do clero quanto de particulares, foi fundamental para o sucesso do trabalho dos membros da Companhia de Jesus e a construção de uma cultura visionária do mundo luso-brasileiro.

Assim como as instituições educacionais foram importantes para a missão cultural dos jesuítas exilados, o fortalecimento do culto a Fátima foi um dos principais aspectos das trocas culturais entre os intelectuais católicos no mundo luso-brasileiro. A construção da igreja dedicada à "Senhora do Rosário" na cidade do Recife foi uma forma de os padres lusitanos compartilharem o principal mito religioso do Portugal contemporâneo, colaborando, assim, com os aspectos da devoção e da crença no país.

Mesmo com a diminuição no número de padres exilados, a partir de 1923, quando alguns religiosos começaram a retornar discretamente a Portugal, ou mesmo após a aprovação

\footnotetext{
${ }^{74}$ SILVA, Laurindo. A visão da Fátima. Diario da Manhã, Recife, p. 93, out. 1935.
} 


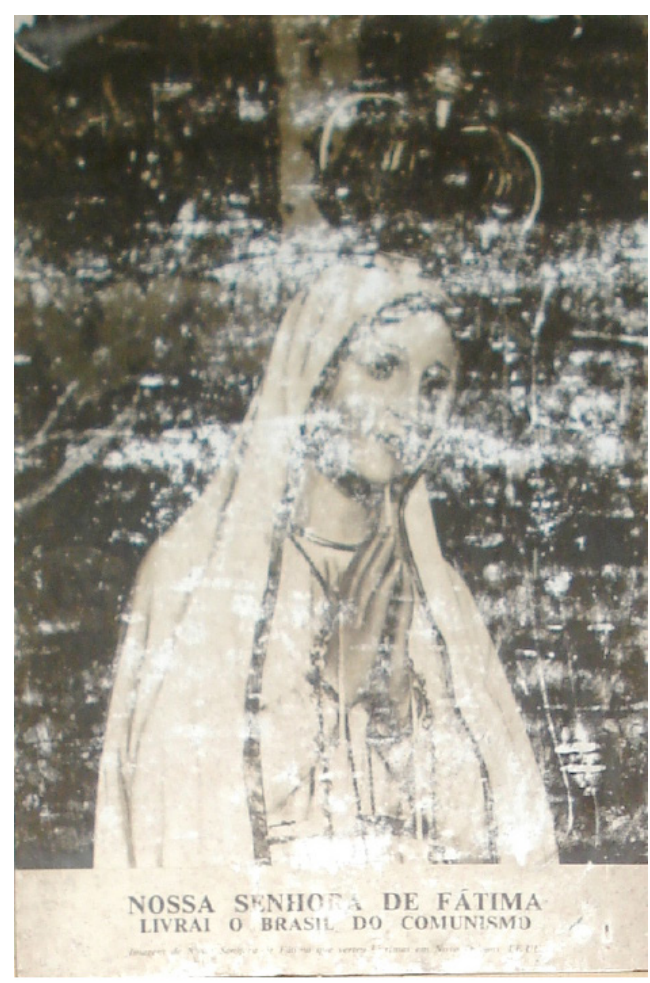

Figura 1 - Imagem de Nossa Senhora de Fátima localizada na Capela do Engenho Uruaé, na cidade de Goiana (PE). Na parte inferior do quadro consta: "Nossa Senhora de Fátima Livrai o Brasil do Comunismo". Fonte: Altar lateral da Capela no Engenho Uruaé.

da constituição lusitana de 1933 que oferecia liberdade ao “(...) culto público ou particular de todas as religiôes, podendo as mesmas organizar-se livremente (...)" ${ }^{75}$ os projetos dos jesuítas continuaram em execução. O retorno dos religiosos ao país de origem colaborou com o processo de independência da Província Portuguesa no Brasil a partir de 1936.

Com as mudanças políticas, a crise financeira na Igreja Católica, os rumores da Segunda Guerra Mundial e as dificuldades para o financiamento do clero, a Companhia de Jesus passou a enfrentar empecilhos para manter a sua estrutura internacional. Para diminuir os gastos com os financiamentos, algumas províncias foram declaradas independentes, como a Vice-província Dependente Setentrional do Brasil, por ser considerada a mais amadurecida. Deste modo, a partir de 8 de dezembro de 1938, a instituiçáo passou a atuar com seus próprios recursos e a organizar o seu corpo administrativo. ${ }^{76}$

As principais críticas à independência da Vice-província do Brasil foi a possibilidade de a instituição não conseguir continuar os projetos iniciados com o Colégio Antônio Vieira em

\footnotetext{
${ }^{75}$ Constituição Política da República Portuguesa. Diário do Govêrno, Lisboa, n. 43, p. 228-236, 22 fev. 1933.

${ }^{76}$ AZEVEDO, Ferdinand. A missão portuguesa da Companhia de Jesus no Nordeste 1911-1936, op. cit., p. 246.
} 
Salvador. Em 1938, a Companhia contava com 60 sacerdotes, 53 irmáos e 40 estudantes. No entanto, a falta de experiência em substituir religiosos que participaram de várias missóes era a principal preocupação de alguns líderes jesuítas. ${ }^{77}$

Mesmo com todo o receio, os membros da Companhia de Jesus que continuaram com os projetos desenvolvidos por seus antecessores foram bem-sucedidos nas atividades relacionadas com a educação e a expansão do culto católico, sobretudo os ligados a Nossa Senhora de Fátima. As suas mensagens foram importantes para o fortalecimento das práticas culturais e religiosas compartilhadas pelos portugueses na sociedade brasileira, tornando-se umas das principais marcas da imigração lusitana. ${ }^{78}$

O processo de imigração dos religiosos contribuiu para o fortalecimento do culto dos católicos portugueses no Brasil. Mesmo resguardando as suas especificidades, os eclesiásticos desenvolveram um intercâmbio importante para a formação cultural dos dois países, principalmente nas questóes relacionadas com a Igreja Católica. As ações pensadas por líderes da Igreja Católica no mundo luso-brasileiro foram fundamentais para a elaboração de uma cultura visionária, importante para a legitimação de um novo culto, que conseguiu captar aspectos sociopolíticos entre o poder civil e religioso.

\section{Fontes}

ALMEIDA, Avelino de. Coisa Espantosa. Como o sol Bailou ao Meio dia em Fátima. $O$ Seculo, Lisboa, p. 1, 15 out. 1917a.

. Em pleno sobrenatural: as apariçóes de Fátima. Milhares de pessoas concorrem a uma charneca nos arredores de Ourem, para verem e ouvirem a Virgem Maria. O Seculo, Lisboa, p. 1, 13 out. 1917c.

. O Milagre de Fátima. Ilustração Portugueza, Lisboa, p. 356, 29 out. 1917b.

Archivio Segreto Vaticano. Nunziatura Apostolica del Brasile (1921-1925). Sacra Congregazione Concistoriale, Roma, 6 out. 1921. Busta 171, fascicolo 932. Doc. 86.

Boletim Mensal da Archidiocese de Olinda e Recife, Recife, ano XI, n. 10-11, p. 201, out./ nov. 1935.

Constituição Política da República Portuguesa. Diário do Govêrno, Lisboa, n. 43, p. 228236, 22 fev. 1933.

Decreto de 20 de abril de 1911. Diario do Governo. Lisboa, n. 92, 21 abr. 1911; CLP, p. 430-446.

\footnotetext{
${ }^{77}$ AZEVEDO, Ferdinand. Procurando sua identidade: a difícil trajetória da Vice-província do Brasil Setentrional da Companhia de Jesus nos anos 1937 a 1952. Recife: FASA, 2006, p. 33.

${ }^{78}$ Ibidem, p. 33, 55.
} 


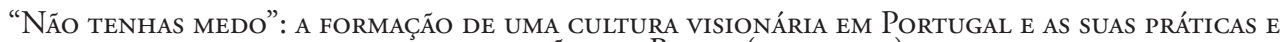
REPRESENTAÇÕES NO BRASIL (I9I7-I940)

Documentação crítica de Fátima II — Processo Canónico Diocesano (1922-1930). Fátima: Santuário de Fátima, 1999.

FERNANDES, Antônio Paulo Ciríaco. Fátima — Santuário mundial. Mensagem divina Rainha da paz, chuva de graças. Recife: Ciclo Cultural Luso-brasileiro, 1944.

LEME, D. Sebastião. Carta pastoral saudando a sua archidiocese. Petrópolis: Typ. Vozes de Petrópolis, 1916.

MONTELO, Visconde. As grandes maravilhas de Fátima: subsídios para a história das apariçóes e dos milagres de Nossa Senhora de Fátima. Lisboa: União Gráfica, 1927.

SILVA, D. José Alves Correia da. Carta pastoral sobre o culto de Nossa Senhora de Fátima. Lisboa: União Gráfica, 1930.

SILVA, Laurindo. A visão da Fátima. Diario da Manhã, Recife, p. 93, out. 1935.

TAVARES, J. S. Fátima e Lourdes. Brotéria. Lisboa, v. XII, fasc. V, p. 273-287, maio 1931.

\section{Referências bibliográficas}

ASSUNÇÃO, Paulo. O Brasil nas páginas da Brotéria. In: RICO, Hermínio; FRANCO, José Eduardo (Coord.). Fé, ciência, cultura: Brotéria - 100 anos. Lisboa: Gradiva, 2003.

AZEVEDO, Carlos Moreira; CRISTINO, Luciano (Coord.). Enciclopédia de Fátima. Estoril: Princípia, 2007.

AZEVEDO, Ferdinand. A missão portuguesa da Companhia de Jesus no Nordeste 1911-1936. Recife: FASA, 1986.

. Procurando sua identidade: a difícil trajetória da Vice-província do Brasil Setentrional da Companhia de Jesus nos anos 1937 a 1952. Recife: FASA, 2006.

AZEVEDO, L. Gonzaga de. Proscritos: notícias circunstanciadas do que passaram os religiosos da Companhia de Jesus na revolução de Portugal de 1910. Bruxelas: Tipografia E. DAEM, 1914. Segunda parte.

BARRETO, José. A Brotéria e Fátima. In: RICO, Hermínio; FRANCO, José Eduardo (Coord.). Fé, ciência, cultura: Brotéria - 100 anos. Lisboa: Gradiva, 2003.

. Religião e sociedade: dois ensaios. Lisboa: Imprensa de Ciências Sociais, 2002.

BERTONE, Tarcisio, SDB. A mensagem de Fátima. Disponível em: <http://www.vatican. va/roman_curia/congregations/cfaith/documents/rc_con_cfaith_doc_20000626_messagefatima_po.html> Acesso em: 2 abr. 2014.

CATROGA, Fernando. Entre deuses e césares: secularização, laicidade e religião civil. Uma perspectiva histórica. Coimbra: Almedina, 2006. 


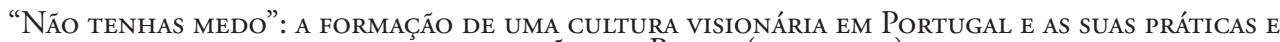
REPRESENTAÇÕES NO BRASIL (I9I7-I940)

. O Republicanismo em Portugal — da formação ao 5 de Outubro de 1910. Lisboa: Notícias editorial, 2000.

CEREJEIRA, D. Manuel Gonçalves. Obras pastorais. Primeiro Volume (1928- 1935). Lisboa: União Gráfica, 1936.

CHRISTIAN JR., William A. Apariciones en Castilla y Cataluña: S. XIV-XV. Madri: Nerea, 1990.

Apparitions in Late Medieval and Renaissance Spain. Princeton: Princeton University Press, 1981.

. De los santos a María. Panorama de las devociones a santuarios españoles desde el principio de la Edad Media hasta nuestros dias. In: TOLOSANA, Carmelo Lison (Coord.). Temas de la antropología española. Madri: Akal, 1976.

. Local Religion in Sixteenth-century Spain. Princeton: Princeton University Press, 1989.

-Visionaries: The Spanish Republic the Reign of Christ. Los Angeles: University of California Press, 1996.

CUNHA, Maria Teresa Pereira da. Nossa Senhora de Fátima Peregrina do Mundo através dos continentes, a caminho de Roma, dos mares e dos ares. Rio de Janeiro: Editora Santa Maria, 1953.

FONTES, Paulo Fernando de Oliveira. Elites católicas em Portugal: o papel da Acção Católica (1940-1961). Lisboa: Fundação Calouste Gulbenkian/Fundação para a Ciência e Tecnologia, 2011.

FOULQUIER, Joseph H. Jesuitas no Norte: segunda entrada da Companhia de Jesus (19111940). Salvador: Vice-Província da Companhia de Jesus no Brasil Setentrional, 1940.

GASBARRO, Nicola. A modernidade ocidental e a generalização de "religião" e "civilização": o agir comunicativo das missóes. In: SILVA, Eliane Moura da; ALMEIDA, Néri de Barros (Org.). Missão e pregação: a comunicação religiosa entre a História da Igreja e a História das Religiōes. São Paulo: FAP/Unifesp, 2014.

. Religione e/o Religioni? la sfida dell'antropologia e della comparazione storicoreligiosa. In: MARANHÃO Fo, Eduardo Meinberg de Albuquerque (Org.). (Re) conhecendo o sagrado: reflexóes teórico-metodológicas dos estudos de religióes e religiosidades. São Paulo: Fonte Editorial, 2013.

KONDOR, Pe. Luís (Comp.). Memórias da irmã Lúcia I. Fátima: Secretariado dos Pastorinhos, 2011.

MATOS, Luís Salgado de. A separaçấo do Estado e da Igreja. Alfragide: D. Quixote, 2011. MATTOSO, José (Dir.); RAMOS, Rui (Coord.). História de Portugal: a segunda fundação (1890-1926). Lisboa: Editorial Estampa, 2001. v. 6. 


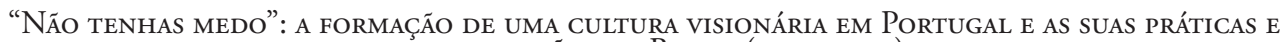
REPRESENTAÇÕES NO BRASIL (I9I7-I940)

MENDES, José Sacchetta Ramos. O apogeu da imigração portuguesa para a América do Sul (1904-1914): diversidade socioeconômica e dilemas comparativos com Itália e Espanha. In: SARMENTO, Cristina Montalvão; GUIMARÃES, Lúcia Maria Paschoal (Coord.). Culturas cruzadas em português: redes de poder e relaçôes culturais (Portugal-Brasil, séc. XIXXX). Influências, ideários, periodismo e ocorrências. Coimbra: Almedina, 2010. v. I.

MOURA, Carlos André Silva de. Histórias cruzadas: debates intelectuais no Brasil e em Portugal durante o movimento de Restauração Católica (1910-1942). 2015, 443 p. Tese (Doutorado em História) — Universidade Estadual de Campinas/Instituto de Filosofia e Ciências Humanas, Campinas, 2015.

. Religiáo e cultura no mundo luso-brasileiro: debates sobre o projeto recatolizador (1910-1937). In: BENATTE, Antônio Paulo; CAMPIGOTO, José Adilçon (Org.). Religião e cultura: temáticas de história cultural das religiôes. Guarapuava: Unicentro, 2013. v. I.

NETO, Vitor. O Estado, A Igreja e a sociedade em Portugal (1832-1911). Lisboa: Imprensa Nacional Casa da Moeda, 1998.

PAIVA, Odair da Cruz. História da (I)migração: imigrantes e migrantes em São Paulo entre o final do século XIX e o início do século XXI. São Paulo: Arquivo Público do Estado, 2013. PINTO, António Costa; FERNANDES, Paulo Jorge. A 1ํㅡ República Portuguesa. Lisboa: CTT, 2010.

RATZINGER, Joseph. Comentário teológico. Disponível em: <http://www.vatican.va/ roman_curia/congregations/cfaith/documents/rc_con_cfaith_doc_20000626_messagefatima_po.html>. Acesso em: 2 abr. 2014.

REIS, Bruno Cardoso. Fátima: a recepção nos diários católicos (1917-1930). Análise Social. Lisboa, p. 249-299, 2001. v. XXXVI (158-159).

SANTA MARIA, Frei Agostinho de. Santuário Mariano, e História das Imagës milagrofas de Nossa Senhora, e das milagrofamente apparecidas, em graça dos Prègadores, \& dos devotos da mefma Senhora. Lisboa: Of. António Pedrozo Galrão, 1707-1723. v. 1-10.

SIMPSON, Duncan. A Igreja Católica e o Estado Novo salazarista. Lisboa: Ediçôes 70, 2014. TORGAL, Luís Felipe. O sol bailou ao meio-dia: a criação de Fátima. Lisboa: Tinta-daChina, 2011. 